\title{
The Haplotype of the TGFß1 Gene Associated with Cerebral Infarction in Chinese
}

\author{
Hong-miao Tao, Guo-zhong Chen, Gan-ping Cheng, Xiao-yun Shan
}

\begin{abstract}
Background: Transforming growth factor beta1 (TGF $\beta 1$ ) is a multifunctional cytokine involved in inflammation and pathogenesis of atherosclerosis. The aim of the present study was to investigate the relationship between human TGF $\beta 1$ gene $+869 \mathrm{~T}>\mathrm{C}$ (rs1800470), -509C>T (rs1800469) single nucleotide polymorphisms (SNPs) and haplotypes and cerebral infarction (CI) in a Chinese population. Methods: The genetic association study was performed in 450 Chinese patients (306 male and 144 female) with CI and 450 control subjects ( 326 male and 124 female). TGF 31 gene $+869 \mathrm{~T}>\mathrm{C}$ and $-509 \mathrm{C}>\mathrm{T}$ polymorphisms were identified with amplification refractory mutation system polymerase chain reaction and DNA sequencing method. Results: The individual SNPs analysis showed the $+869 \mathrm{~T}$ and $-509 \mathrm{C}$ in an additive model (+869T vs $+869 \mathrm{C}$; $-509 \mathrm{C}$ vs T), +869TT genotype in a recessive model (TT vs TC+CC) and $509 \mathrm{CC}$ genotype in a dominant model (CC+CT vs TT) were identified to be related to CI $(\mathrm{P}<0.05)$. $+869 \mathrm{~T}>\mathrm{C}$ and $-509 \mathrm{C}>\mathrm{T}$ SNPs were in strong linkage disequilibrium $\left(\mathrm{d}^{\prime}=0.87, \mathrm{R}^{2}=0.75\right)$. Haplotype analysis showed that $+869 \mathrm{C} /-509 \mathrm{~T}$ haplotype was associated with a significant decreased risk of $\mathrm{CI}(\mathrm{OR}=0.86,95 \% \mathrm{CI}, 0.70-0.92 ; \mathrm{P}=0.007)$. Furthermore, $+869 \mathrm{~T} /-509 \mathrm{C}$ haplotype was associated with a significant increased risk of $\mathrm{CI}(\mathrm{OR}=1.31,95 \% \mathrm{CI}, 1.10-2.03 ; \mathrm{P}=0.019)$. Conclusions: The results of this study indicate that polymorphisms and the haplotypes in the TGF $\beta 1$ gene might be genetic markers for $\mathrm{CI}$ in the Chinese population.
\end{abstract}

RÉSUMÉ: Haplotype du gène TGFß1 associé à l'infarctus cérébral chez les Chinois. Contexte : Le facteur de croissance transformant bêta (TGF $\beta 1$ ) est une cytokine plurifonctionnelle impliquée dans l'inflammation et la pathogenèse de l'athérosclérose. Le but de cette étude était d'explorer la relation entre les polymorphisme d'un seul nucléotide (SNP) +869T >C (site de restriction 1800470), $-509 \mathrm{C}>\mathrm{T}$ (site de restriction 1800469) ainsi que les haplotypes du gène TGF $\beta 1$ et l'infarctus cérébral (IC) dans une population chinoise. Méthode : Nous avons procédé à une étude d'association génétique chez 450 patients chinois (306 hommes et 144 femmes) atteints d'un IC et 450 sujets témoins (326 hommes et 124 femmes). Les polymorphismes $+869 \mathrm{~T}>\mathrm{C}$ et $-509 \mathrm{C}>\mathrm{T}$ du gène TGF $\beta 1$ ont été identifiés par système de mutation réfractaire à l'amplification par PCR et séquençage d'ADN. Résultats : L'analyse de chacun des SNP a démontré que $+869 \mathrm{~T}$ et $-509 \mathrm{C}$ dans un modèle additif $(+869 \mathrm{~T}$ versus $+869 \mathrm{C}$; $-509 \mathrm{C}$ versus T), le génotype +869TT dans un modèle récessif $(\mathrm{TT}$ versus $\mathrm{TC}+\mathrm{CC}$ ) et le génotype $509 \mathrm{CC}$ dans un modèle dominant $(\mathrm{CC}+\mathrm{CT}$ versus TT) étaient reliés à l'IC $(\mathrm{P}<0,05)$. Les $\mathrm{SNP}+869 \mathrm{~T}>\mathrm{C}$ et $-509 \mathrm{C}>\mathrm{T}$ étaient fortement en déséquilibre de liaison $\left(\mathrm{d}^{\prime}=0,87, \mathrm{R} 2=0,75\right)$. L'analyse des haplotypes a démontré que l'haplotype $+869 \mathrm{C} /-509 \mathrm{~T}$ était associé à une diminution significative du risque d'IC ( $\mathrm{RC}+0,86, \mathrm{IC}$ à 95\% 0,70 à 0,92; $\mathrm{p}=0,007)$. De plus, l'haplotype $+869 \mathrm{~T} /-509 \mathrm{C}$ était associé à une augmentation significative du risque d'IC $(\mathrm{RC}=1.31$. IC à $95 \% 1,10$ à 2,$03 ; \mathrm{p}=0,019)$. Conclusions $:$ Les résultats de cette étude indiquent que des polymorphismes et des haplotypes du gène TGF $\beta 1$ pourraient être des marqueurs génétiques de l'IC dans la population chinoise.

Can J Neurol Sci. 2012; 39: 626-631

Cerebral infarction (CI) is one of the most common causes of death and disability ${ }^{1}$ with a complex etiology involving both genetic and environmental contributions ${ }^{2,3}$. Recent advances have revealed that inflammation is an essential process in the pathogenesis of $\mathrm{CI}^{4}$. Inflammation is influenced by many different cytokines, such as transforming growth factor betal (TGF $\beta 1$ ), the most common variant of 3 isoforms (TGF $\beta 1,2$ and $3)$. The TGF $\beta 1$ gene is located on chromosome 19q13. It comprises seven exons and nine introns and produces mRNA of $2.5 \mathrm{~kb}^{5}$. There are several commonly known (potentially) functional polymorphisms in this gene. The production of TGF $\beta 1$ is predominantly under genetic control and several single nucleotide polymorphisms (SNPs) in human TGF $\beta 1$ have been identified. Two functional SNPs, +869T $>$ C $(29 \mathrm{~T}>\mathrm{C}$ or Leu10pro, rs1800470) and-509C $>\mathrm{T}(-1347 \mathrm{C}>\mathrm{T}$, rs1800469) have been reported to modify the serum level of TGF $\beta 1^{6-8}$.
To date, few studies have been published on the association of the TGF $\beta 1$ polymorphism and risk of $\mathrm{CI}^{9-11}$. The sparse results available are inconsistent. All of these studies have focused on independent associations with single SNPs, with only one examining TGF $\beta 1$ haplotypes ${ }^{11}$. However, haplotype-based

From the School of Medicine (HMT, GZC), Jinhua College of Profession \& Technology, Jinhua City; Department of Neurology (GPC), Jinhua People's Hospital, Department of Clinical Laboratory (XYS), Jinhua Central Hospital, Jinhua, Zhejiang Province, The People's Republic of China.

Received February 10, 2012. Final Revisions Submitted May 3, 2012. Correspondence to: Xiao-yun Shan, Department of Clinical Laboratory, Jinhua Central Hospital, Jinhua 321000, Zhejiang Province, the People's Republic of China. Email: shxyun111@163.com. 
association studies have been proposed as a powerful and comprehensive approach for mapping causal genetic variation underlying complex disease, such as $\mathrm{CI}^{12-14}$. Therefore, we conducted this case control study, to investigate the relationship between of SNPs and haplotypes in TGF $\beta 1$ gene and CI.

\section{Materials ANd Methods}

\section{Study Population}

The study protocol included history taking, neurological examination, extracranial and transcranial ultrasound, neuroimaging and laboratory testing. This study was conducted on patients who were consecutively admitted to the Department of Neurology of Jinhua Central Hospital and Jinhua People's Hospital (July, 2007 to December, 2011). A total of 450 consecutive patients presenting with CI were recruited. The diagnosis of CI was defined as ischemic stroke with signs and symptoms lasting $>24$ hours and having relevant lesions as detected by magnetic resonance imaging (MRI) or computed tomogram (CT). All patients with CI were further categorized into its subtypes using Trial of Org10172 in Acute Stroke Treatment (TOAST) classification ${ }^{15}$. Patients with potential sources of cardio-embolism (e.g., atrial fibrillation, recent myocardial infarction, mechanical prosthetic valve, dilated myocardiopathy, and mitral rheumatic stenosis.) were excluded from study. History taking, physical examination, and routine diagnostic tests (electrocardiogram and findings on neuroimaging studies) were sufficient to easily make the diagnosis of most presumed cardiac emboligenic conditions (e.g., atrial fibrillation, recent myocardial infarction, prior rheumatic disease, valve replacement surgery). Echocardiography (both transthoracic and/or transoesophageal) was used to reveal structural cardiopathies (dilated cardiomyopathies, mitral stenosis and mechanical prosthetic valve). As a result, 189 patients had large artery atherosclerosis, 201 had small vessel occlusion (SVO), and 60 were diagnosed as stroke with other determined etiology or stroke of undetermined etiology. Based on negative history of stroke and negative findings of brain CT or MRI, a total of 450 control subjects without CI were recruited during their routine annual health check-up from the same geographic locations as the patients.. Sampling was stratified to a similar distribution of age, sex and conventional vascular risk factors as the patients in the study. The subjects highly suspected of having a stroke were excluded by performing a CT or MRI scan.

The evaluation of risk factors in both cases and controls included age, sex, body mass index (BMI, $\mathrm{kg} / \mathrm{m}^{2}$ ), hyperlipemia, smoking status, hypertension and diabetes mellitus. Systemic arterial hypertension was defined as a systolic blood pressure of $140 \mathrm{~mm} \mathrm{Hg}$, and/or a diastolic blood pressure of $90 \mathrm{~mm} \mathrm{Hg}$, at least on two separate occasions, or antihypertensive treatment. Hyperlipemia was defined as either an elevated fasting total cholesterol level above $220 \mathrm{mg} / \mathrm{dL}(5.7 \mathrm{mmol} / \mathrm{l})$ or fasting triglyceride level above $150 \mathrm{mg} / \mathrm{dl}(1.7 \mathrm{mmol} / \mathrm{l})$ or current treatment with lipid-lowering medication ${ }^{16}$. Current or former smokers were defined as having used tobacco for one or more years. Diabetes mellitus was defined as the presence of an active treatment with insulin or an oral antidiabetic agent; for patients administered dietary treatment, documentation of abnormal fasting blood glucose or glucose tolerance test based on the World Health Organization criteria was required for establishing this diagnosis.

All patients and control subjects were Chinese. They were all unrelated. Written informed consent was obtained from all subjects. The study protocol was approved by the Medical Ethics Committee of Jinhua.

\section{SNP Selection and Genotyping}

Based on the allelic frequency data for registered SNPs from NCBI dbSNP (http://www.ncbi.nlm.nih.gov/SNP/) databases, SNPs with minor allele frequency $>5 \%$ were chosen for study.

Venous blood $(5 \mathrm{ml})$ was collected into tubes containing EDTA (disodium salt, $50 \mathrm{mmol} / \mathrm{L}$ ), and genomic DNA was

Table 1: Baseline characteristic of the study populaiton

\begin{tabular}{llll}
\hline Characteristic & CI group $(\mathrm{n}=450)$ & Controls $(\mathrm{n}=450)$ & P value \\
\hline Age, years & $64.87 \pm 14.45$ & $63.85 \pm 13.80$ & 0.13 \\
Male,n $(\%)$ & $306(68.00)$ & $326(72.44)$ & 0.16 \\
BMI,kg/m ${ }^{2}$ & $24.23 \pm 7.66$ & $23.68 \pm 6.80$ & 0.11 \\
Hyperlipemia,n $(\%)$ & $93(21.98)$ & $96(22.75)$ & 0.79 \\
Smoking, $\mathrm{n}(\%)$ & $188(42.53)$ & $179(40.32)$ & 0.50 \\
Hypertension, $\mathrm{n}(\%)$ & $268(59.56)$ & $219(48.67)$ & 0.001 \\
Diabetes,n $(\%)$ & $86(19.11)$ & $75(16.67)$ & 0.34 \\
\hline
\end{tabular}


isolated with a DNA extraction kit (Roche, Switzerland). Genotyping of the $+869 \mathrm{~T}>\mathrm{C}$ and $-509 \mathrm{C}>\mathrm{T}$ polymorphisms of TGF $\beta 1$ were performed by the amplification refractory mutation system polymerase chain reaction (ARMS-PCR) method ${ }^{17,18}$. All reagents for PCR were purchased from Roche Diagnostics (Roche, Switzerland). The primers were synthesized at the SBS Genetech Co (Beijing, China). The ARMS-PCR technique uses four primers as follows: a forward outer primer, a reverse outer primer, a forward inner wild type specific primer and a reverse inner mutant specific primer. PCR reaction was performed within a total volume of $25 \mu \mathrm{L}$ containing $2 \mu \mathrm{L} 10 \mathrm{x}$ PCR buffer (Mg2+ Plus), $2 \mu \mathrm{L} 2.5 \mathrm{mM}$ Dntp, $0.5 \mu \mathrm{L}$ each primer $(10 \mu \mathrm{M}), 2$ $\mu \mathrm{L}$ genome samples and distilled water. PCR amplification conditions were an initial denaturation at $94^{\circ} \mathrm{C}$ for 8 minutes, followed by 20 cycles of melting at $94^{\circ} \mathrm{C}$ for 30 s, annealing at $58^{\circ} \mathrm{C}$ (869 site) and $60^{\circ} \mathrm{C}$ (509 site) for $30 \mathrm{~s}$, and extension at $72^{\circ} \mathrm{C}$ for $40 \mathrm{~s}$, with final extension at $72^{\circ} \mathrm{C}$ for 5 minutes.

The TGF $\beta 1$ genotype was determined by $2.0 \%$ agarose-gel electrophoresis of PCR products followed by ethidium bromide staining. The $869 \mathrm{C}$ allele produced a 248 -bp fragment, whereas $869 \mathrm{~T}$ allele produced a 290-bp fragment. The $-509 \mathrm{C}$ allele produced a 507-bp fragment, whereas $-509 \mathrm{~T}$ allele produced a 248-bp fragment.

The DNA sequencing was performed on 140 random samples. It confirmed the match between the product sequence and the established TGF $\beta 1$ sequence.

\section{Statistical Analysis}

Power and Sample Size Calculation Software 2.1 was used for sample size calculation. We assumed $\alpha=0.05$ (two-sided) with power $=80 \%$ using a $1: 1$ ratio of cases to controls while looking for an odds ratio (OR) of 1.5. We assumed the rate of $+869 \mathrm{TT}$ or -509CC genotype in the source population (controls) is $30 \%$. It indicates that $n=425$ cases and controls are required in this study.

SPSS statistical software version 10.0 was used for statistical analysis. Data are presented as the mean \pm SD. Statistical significance was tested using unpaired Student's t-test or the Mann-Whitney U test as appropriate. Qualitative data were compared by the chi-square test. Allele frequencies were estimated by the gene-counting method, and chi-square test was performed to test for deviations from Hardy-Weinberg

Table 2: Genotype distributions and allele frequencies of the $+869 \mathrm{~T}>\mathrm{C}$ and $-509 \mathrm{C}>\mathrm{T}$

\begin{tabular}{|c|c|c|c|c|c|}
\hline \multicolumn{3}{|l|}{ Polymorphysim } & \multicolumn{2}{|l|}{ CI group $(n=450)$} & \multirow{2}{*}{$\frac{\text { Controls }(n=450)}{122(27.11)}$} \\
\hline \multirow{11}{*}{$+869 \mathrm{~T}>\mathrm{C}$} & \multirow{3}{*}{ Genotype } & $\mathrm{CC}, \mathrm{n}(\%)$ & \multicolumn{2}{|l|}{$105(23.33)$} & \\
\hline & & TC,n (\%) & \multicolumn{2}{|l|}{$193(42.89)$} & $217(48.22)$ \\
\hline & & $\mathrm{TT}, \mathrm{n}(\%)$ & \multicolumn{2}{|l|}{$152(33.78)$} & $111(24.67)$ \\
\hline & \multirow{2}{*}{ Allele } & $\mathrm{C},(\%)$ & \multicolumn{2}{|l|}{44.78} & 51.22 \\
\hline & & $\mathrm{T},(\%)$ & \multicolumn{2}{|l|}{55.22} & 48.78 \\
\hline & Dominant & OR (95\%CI);P & $1.22(0.90-1.65)$ & 0.192 & \\
\hline & $(\mathrm{TT}+\mathrm{TC}$ versus $\mathrm{CC})$ & adjust & $1.27(0.93-1.75)$ & 0.136 & \\
\hline & Recessive & OR $(95 \% \mathrm{CI}) ; \mathrm{P}$ & $1.56(1.17-2.08)$ & 0.003 & \\
\hline & (TT versus $\mathrm{TC}+\mathrm{CC}$ ) & adjust & $1.58(1.16-2.14)$ & 0.003 & \\
\hline & Additive & OR $(95 \% \mathrm{CI}) ; \mathrm{P}$ & $1.22(0.99-1.51)$ & 0.065 & \\
\hline & (T versus $\mathrm{C}$ ) & adjust & $1.27(1.02-1.59)$ & 0.035 & \\
\hline \multirow{11}{*}{$-509 \mathrm{C}>\mathrm{T}$} & \multirow{3}{*}{ Genotype } & $\mathrm{TT}, \mathrm{n}(\%)$ & $78(17.33)$ & & $114(25.33)$ \\
\hline & & $\mathrm{CT}, \mathrm{n}(\%)$ & $248(55.11)$ & & $233(51.78)$ \\
\hline & & CC,n $(\%)$ & $124(27.56)$ & & $103(22.89)$ \\
\hline & \multirow{2}{*}{ Allele } & $\mathrm{T},(\%)$ & \multicolumn{2}{|l|}{44.89} & 51.22 \\
\hline & & $\mathrm{C},(\%)$ & \multicolumn{2}{|l|}{55.11} & 48.78 \\
\hline & Dominant & OR $(95 \% \mathrm{CI}) ; \mathrm{P}$ & $1.61(1.17-2.26)$ & 0.004 & \\
\hline & $(\mathrm{CC}+\mathrm{CT}$ versus $\mathrm{TT})$ & Adjust & $1.66(1.17-2.36)$ & 0.004 & \\
\hline & Recessive & OR $(95 \% \mathrm{CI}) ; \mathrm{P}$ & $1.28(0.95-1.73)$ & 0.125 & \\
\hline & ( $\mathrm{CC}$ versus $\mathrm{TT}+\mathrm{CT}$ ) & Adjust & $1.33(0.96-1.86)$ & 0.088 & \\
\hline & Additive & OR $(95 \% \mathrm{CI}) ; \mathrm{P}$ & $1.28(1.07-1.55)$ & 0.008 & \\
\hline & $(\mathrm{C}$ versus $\mathrm{T}$ ) & Adjust & $1.30(1.07-1.59)$ & 0.01 & \\
\hline
\end{tabular}


Table 3: Haplotype frequency distribution of the TGFß1 and its relationship with CI

\begin{tabular}{llllll}
\hline Haplotype & Cl group, $\mathrm{n}(\%)$ & Controls, $\mathrm{n}(\%)$ & $\mathrm{X}^{2}$ & P value & OR (95\%Cl) \\
\hline +869C/ -509C & $39.83(0.04)$ & $18.38(0.017)$ & 8.17 & 0.004 & $2.22(1.27-3.89)$ \\
+869T /-509C & $456.17(0.51)$ & $420.62(0.47)$ & 2.81 & 0.09 & $1.17(0.97-1.41)$ \\
+869C /-509T & $363.17(0.40)$ & $442.63(0.49)$ & 14.19 & 0.0001 & $0.70(0.58-0.84)$ \\
+869T /-509 T & $40.83(0.05)$ & $18.38(0.016)$ & 8.81 & 0.003 & $2.28(1.30-3.99]$ \\
\hline
\end{tabular}

equilibrium. Logistic regression models were used for calculating odds ratios $(95 \%$ confidence interval $(\mathrm{CI})$ and corresponding $\mathrm{P}$ values, controlling for age (continuous value), gender (female $=0$, male $=1$ ) and the presence of risk factors (negative $=0$, positive $=1$ ) as co-variates. TGF $\beta 1$ genotype was calculated according to a dominant $(+869 \mathrm{~T}>\mathrm{C}: \mathrm{CC}=0$, $\mathrm{TC}=\mathrm{TT}=1 ;-509 \mathrm{C}>\mathrm{T}: \mathrm{TT}=0, \mathrm{CT}=\mathrm{CC}=1)$, recessive $(+869 \mathrm{~T}>\mathrm{C}$ : $\mathrm{TC}=\mathrm{CC}=0, \mathrm{TT}=1 ;-509 \mathrm{C}>\mathrm{T}: \mathrm{CT}=\mathrm{TT}=0, \mathrm{CC}=1)$ and additive genetic model $(+869 \mathrm{~T}>\mathrm{C}: \mathrm{C}=0, \mathrm{~T}=1 ;-509 \mathrm{C}>\mathrm{T}: \mathrm{T}=0, \mathrm{C}=1)$. The $\mathrm{OR}$ and $95 \% \mathrm{CI}$ were also calculated. Statistical significance was taken as $\mathrm{P}<0.05$ ( 2 tailed).

The linkage disequilibrium and haplotype analysis $\left(\mathrm{D}^{\prime}\right.$ and $\left.\mathrm{r}^{2}\right)$ were performed using the online software SHEsis (http://analysis.bio-x.cn/myAnalysis.php). The threshold value of the frequencies of the haplotypes included in the analysis was set to $2 \%$. All haplotypes below the threshold value were excluded from the analysis.

\section{RESULTS}

Clinical characteristics of the patients with CI and controls are summarized in Table1. There were no significant differences in age, sex, BMI or conventional risk factors ( $\mathrm{P}>0.05$; Table 1 ). We found that the prevalence of hypertension was more frequent among CI patients than control group $(\mathrm{P}<0.05$, Table 1$)$.

The genotype distribution and the allele frequency for $+869 \mathrm{~T}>\mathrm{C}$ and $-509 \mathrm{C}>\mathrm{T}$ polymorphisms are shown in Table 2. The genotype distributions among patients and controls were in Hardy-Weinberg equilibrium $\left(+869 \mathrm{~T}>\mathrm{C}: \mathrm{X}^{2}=0.55, P=0.45\right.$, $\left.\mathrm{df}=1 ;-509 \mathrm{C}>\mathrm{T}: \mathrm{X}^{2}=0.59, P=0.44, \mathrm{df}=1\right)$. Analysis demonstrated that there were significant differences in the overall distribution of genotypes and allele of $+869 \mathrm{~T}>\mathrm{C}$ and $-509 \mathrm{C}>\mathrm{T}$ between the $\mathrm{CI}$ and the control groups. The univariate analysis showed that subjects carrying $+869 \mathrm{TT}$ genotype were at a 1.56 -fold elevated risk for $\mathrm{CI}(\mathrm{OR}=1.56,95 \% \mathrm{CI}, 1.17-2.08 ; \mathrm{P}=0.003)$ as compared with those carrying TC and $\mathrm{CC}$ genotype. A marginally significant increase in risk of CI was found in +869T allele carriers as compared with the $+869 \mathrm{C}$ allele carriers $(\mathrm{OR}=1.22$, $95 \%$ CI, $0.99-1.51 ; \mathrm{P}=0.065)$. Subjects carrying the $-509 \mathrm{C}$ allele $(\mathrm{CC}+\mathrm{CT})$ were at a 1.61 -fold elevated risk for $\mathrm{CI}(\mathrm{OR}=1.61$, $95 \% \mathrm{CI}, 1.17-2.26 ; \mathrm{P}=0.004$ ) as compared those homozygous for the $-509 \mathrm{TT}$ genotype. The $\mathrm{C}$ allele at $-509 \mathrm{C}>\mathrm{T}$ was also

Table 4: Summary of studies on the association between TGFß1 gene polymorphism and CI

\begin{tabular}{|c|c|c|c|c|c|c|}
\hline Authors, year & Study type & Sample size & $\begin{array}{c}\text { Geographical } \\
\text { location }\end{array}$ & Investigated SNPs & $\begin{array}{c}\text { Sex } \\
\text { stratification }\end{array}$ & $\begin{array}{c}\text { Results } \\
\text { (CI -related SNPs } \\
\text { or haplotypes) }\end{array}$ \\
\hline Sie et al,2006 $6^{[10]}$ & $\begin{array}{l}\text { Prospective } \\
\text { cohort study }\end{array}$ & 6456 & $\begin{array}{l}\text { Rotterdam, } \\
\text { Netherland }\end{array}$ & $\begin{array}{l}-800 \mathrm{G} / \mathrm{A} ; 509 \mathrm{C} / \mathrm{T} \\
+869 \mathrm{~T} / \mathrm{C} ;+915 \mathrm{G} / \mathrm{C} \\
+11929 \mathrm{C} / \mathrm{T}\end{array}$ & no & none \\
\hline Kim et al,2006 $6^{[9]}$ & Case-control & $\begin{array}{c}\text { case: } 271 \\
\text { control: } 207\end{array}$ & Korea & $+869 \mathrm{~T} / \mathrm{C}$ & no & $+869 \mathrm{~T} / \mathrm{C}$ \\
\hline Peng et al, $2011^{[11]}$ & Case-control & $\begin{array}{c}\text { case: } 186 \\
\text { control: } 160\end{array}$ & $\begin{array}{l}\text { Changsha, Hunan } \\
\text { Province ,China }\end{array}$ & $\begin{array}{l}-800 \mathrm{G} / \mathrm{A} ; 509 \mathrm{C} / \mathrm{T} \\
+869 \mathrm{~T} / \mathrm{C}\end{array}$ & yes & $509 \mathrm{C} / \mathrm{T} ;+869 \mathrm{~T} / \mathrm{C}$ \\
\hline Tao et al & Case-control & $\begin{array}{c}\text { case: } 450 \\
\text { control: } 450\end{array}$ & $\begin{array}{l}\text { Jinhua,Zhejiang } \\
\text { Province,China }\end{array}$ & $\begin{array}{l}-800 \mathrm{G} / \mathrm{A} ; 509 \mathrm{C} / \mathrm{T} \\
+869 \mathrm{~T} / \mathrm{C}\end{array}$ & no & $\begin{array}{c}509 \mathrm{C} / \mathrm{T} ;+869 \mathrm{~T} / \mathrm{C} \\
+869 \mathrm{~T} /-509 \mathrm{C}\end{array}$ \\
\hline
\end{tabular}


identified to be related to $\mathrm{CI}(\mathrm{OR}=1.28,95 \% \mathrm{CI}, 1.07-1.55$; $\mathrm{P}=$ 0.008 ).

Further analysis in a multiple logistic regression model revealed that the positive relationships between the +869TT genotype in a recessive model (TT vs TC+CC), $-509 \mathrm{C}$ allele in additive model (C vs T) and -509CC genotype in a dominant model $(\mathrm{CC}+\mathrm{CT}$ vs TT) and $\mathrm{CI}$ remained unchanged $(\mathrm{P}<0.05)$; However, the marginally significant association between the $+869 \mathrm{~T}$ allele and CI revealed by the univariate analysis changed (adjusted $\mathrm{OR}=1.27, P=0.035$ ) .

Table 3 presents the haplotype frequency distribution of the TGF $\beta 1$ and its relationship with CI. Strong linkage disequilibrium $\left(\mathrm{d}^{\prime}=0.87, \mathrm{R}^{2}=0.75\right)$ is detected between two SNPS in TGF $\beta 1$ gene. In the haplotype analysis of $+869 \mathrm{~T}>\mathrm{C}$ and $509 \mathrm{C}>\mathrm{T}$, four haplotypes were identified. In accordance with the principles of haplotype analysis, the $+869 \mathrm{C} /-509 \mathrm{C}$ and $+869 \mathrm{~T} /-$ 509T haplotypes in control group were excluded in case-control studies because the frequencies are less than 0.02 (http//www.hapmap.org). Haplotype of $+869 \mathrm{C} /-509 \mathrm{~T}$ was significantly less frequent in the CI group $(40.0 \%)$ than in the non-CI group (49\%) $(P<0.05)$, whereas $+869 \mathrm{~T} /-509 \mathrm{C}$ haplotype distribution was marginally significant $(0.1>\mathrm{P}>0.05)$ (Table 3$)$. Multiple regression analysis shows that $+869 \mathrm{C} /-509 \mathrm{~T}$ haplotype was associated with a significant decreased risk of $\mathrm{CI}(\mathrm{OR}=0.86$, 95\% CI, $0.70-0.92 ; P=0.007)$. Furthermore, $+869 \mathrm{~T} /-509 \mathrm{C}$ haplotype was associated with a significant increased risk of CI $(\mathrm{OR}=1.31,95 \% \mathrm{CI}, 1.10-2.03 ; P=0.019)$.

\section{DisCUSSION}

The present study revealed that the $-509 \mathrm{C}>\mathrm{T},+869 \mathrm{~T}>\mathrm{C}$ polymorphisms of the TGF $\beta 1$ gene were associated with susceptibility to $\mathrm{CI}$ in a Chinese population. The major findings of our study were as follows: (1) +869T allele, +869TT genotype in a recessive model, -509C allele and -509CC genotype in an additive model were identified independently to be related to CI. (2) $+869 \mathrm{~T} /-509 \mathrm{C}$ haplotype was associated with significantly increased risks of CI. Although the prevalence of hypertension was more frequent among CI patients than control group, we have selected the logistic regression analysis to minimise the confounding bias.

Few studies examined the TGF $\beta 1$ gene variant as a risk factor in stroke $\mathrm{e}^{8-10}$. The sparse results available are inconsistent. Table 4 shows studies on the association between TGF $\beta 1$ gene polymorphism and CI. The positive association between the +869TT genotype and the risk of ischemic stroke $(\mathrm{OR}=1.63$, $\mathrm{P}=0.026$ ) in a Korean population ${ }^{9}$ were in accordance with our results. However,the results in our present study provided more convincing evidence of a causal relationship between TGF $\beta 1$ and CI because of controlling confounding variables and large numbers $(n=900)$ of subjects. In the large prospective cohort study with more than 6000 Caucasians individuals, $+869 \mathrm{C}$ allele and $-509 \mathrm{~T}$ was found to be a risk factor for stroke as a whole but not for ischemic stroke ${ }^{10}$. In contrast, another case-control study from a Chinese population showed that alleles of $-509 \mathrm{~T}$ and $+869 \mathrm{C}$ and haplotype of $-509 \mathrm{~T} /+869 \mathrm{C}$ were more frequent in CI patients than in controls ${ }^{11}$.

A high degree of linkage disequilibrium was observed between pairs of the $+869 \mathrm{~T}>\mathrm{C}$ and $-509 \mathrm{C}>\mathrm{T}$ SNPs in our study, in agreement with previous studies ${ }^{19,20}$. In this regard, further haplotype analysis of the two polymorphisms was conducted, which is more useful for the identification of predisposing genes of complicated diseases ${ }^{12-14}$. Results in the present study demonstrated that $+869 \mathrm{~T} /-509 \mathrm{C}$ haplotype was associated with a higher risk for developing CI. The risk of CI occurring in subjects carrying this haplotype was 1.31 -fold higher $(\mathrm{P}=0.019)$ than in those without the $+869 \mathrm{~T} /-509 \mathrm{C}$ haplotype. Conversly, Peng et al found the frequency of the $+869 \mathrm{C} /-509 \mathrm{~T}$ combined genotype was significantly higher in the $\mathrm{CI}$ group than in controls $(\mathrm{P}<0.001)^{11}$.

There are several potential explanations for the divergent results. One important aspect is genetic heterogeneity; different TGF 1 SNPs may be involved in different populations and the pathology of the disease may also differ between the populations. Another important aspect to consider in this context is phenotypic heterogeneity. The etiology of CI is heterogeneous and genetic factors may vary by etiologic subtype. Unlike our present study, cardioembolic CI patients have not been excluded in the analysis in most of the previous studies 9,10 .

It has been well documented that TGF $\beta 1$ is a pleiotropic cytokine with potent anti-inflammation properties ${ }^{21}$. Therefore, it is conceivable that subjects carrying $+869 \mathrm{~T}$ or $-509 \mathrm{C}$ alleles might be at greater risk for CI, because such alleles are associated with decreased TGF $\beta 1$ level $6,8,22$.

The potential limitations of our study warrant consideration. Firstly, we may not have captured all common genetic variations in TGF $\beta 1$ in this study and we genotyped variants that are likely to have a functional impact on the expression or activation of TGF $\beta 1$, and thus, which may be more important for CI risk. Secondly, as all study subjects are Chinese, our results may not be generalized to other ethnic populations with different environmental exposures. Additional studies are needed to confirm these findings. Finally, it is not possible to completely exclude potential statistical errors such as false-positives.

\section{CONCLUSION}

In conclusion, we found that the $-509 \mathrm{C}>\mathrm{T}$ and $+869 \mathrm{~T}>\mathrm{C}$ polymorphisms of the TGF $\beta 1$ gene were associated with susceptibility to $\mathrm{CI}$ in a Chinese population. This study gives additional support to the important role of inflammation in the pathogenesis of CI.

\section{SOURCE OF FUNDING}

This study was supported by a grant of the Jinhua Science and Technology Bureau project, Zhejiang Province, The People's Republic of China (No: 2008-3-055).

\section{REFERENCES}

1. Feigin VL, Lawes CM, Bennett DA, Anderson CS. Stroke epidemiology: a review of population-based studies of incidence, prevalence, and case-fatality in the late 20th century. Lancet Neurol. 2003;2:43-53.

2. Pezzini A, Grassi M, Del Zotto E, et al. Cumulative effect of predisposing genotypes and their interaction with modifiable factors on the risk of ischemic stroke in young adults. Stroke. 2005;36:533-9.

3. Hassan A, Markus HS. Genetics and ischaemic stroke. Brain. 2000; 123 (Pt 9):1784-812.

4. Libby P. Inflammation in atherosclerosis. Nature. 2002;420:868-74. 
5. Fujii D, Brissenden JE, Derynck R, Francke U. Transforming growth factor beta gene maps to human chromosome 19 long arm and to mouse chromosome 7. Somat Cell Mol Genet. 1986; $12: 281-8$

6. Grainger DJ, Heathcote K, Chiano M, et al. Genetic control of the circulating concentration of transforming growth factor type beta1. Hum Mol Genet. 1999;8:93-7.

7. Dunning AM, Ellis PD, McBride S, et al. A transforming growth factor betal signal peptide variant increases secretion in vitro and is associated with increased incidence of invasive breast cancer. Cancer Res. 2003;63:2610-15.

8. Yokota M, Ichihara S, Lin TL, Nakashima N, Yamada Y. Association of a T29-->C polymorphism of the transforming growth factor-betal gene with genetic susceptibility to myocardial infarction in Japanese. Circulation. 2000;101: 2783-7.

9. Kim Y, Lee C. The gene encoding transforming growth factor beta 1 confers risk of ischemic stroke and vascular dementia. Stroke. 2006;37:2843-5.

10. Sie MP, Uitterlinden AG, Bos MJ, et al. TGF-beta 1 polymorphisms and risk of myocardial infarction and stroke: the Rotterdam Study. Stroke. 2006;37:2667-71.

11. Peng Z, Zhan L, Chen S, Xu E. Association of transforming growth factor-beta1 gene C-509T and T869C polymorphisms with atherosclerotic cerebral infarction in the Chinese: a case-control study. Lipids Health Dis. 2011;10:100.

12. Johnson GC, Esposito L, Barratt BJ, et al. Haplotype tagging for the identification of common disease genes. Nat Genet. 2001;29: 233-7.

13. Weiss KM, Terwilliger JD. How many diseases does it take to map a gene with SNPs? Nat Genet. 2000;26:151-7.

14. Chanock S. Genetic variation and hematology: single-nucleotide polymorphisms, haplotypes, and complex disease. Semin Hematol. 2003;40:321-8.
15. Adams HP, Jr., Bendixen BH, Kappelle LJ, et al. Classification of subtype of acute ischemic stroke. Definitions for use in a multicenter clinical trial. TOAST. Trial of Org 10172 in Acute Stroke Treatment. Stroke. 1993;24:35-41.

16. Hata Y, Mabuchi H, Saito Y, et al. Report of the Japan Atherosclerosis Society (JAS) guideline for diagnosis and treatment of hyperlipidemia in Japanese adults. J Atheroscler Thromb. 2002;9:1-27.

17. Jones AV, Kreil S, Zoi K, et al. Widespread occurrence of the JAK2 V617F mutation in chronic myeloproliferative disorders. Blood. 2005; 106:2162-8.

18. Newton CR, Graham A, Heptinstall LE, et al. Analysis of any point mutation in DNA. The amplification refractory mutation system (ARMS). Nucleic Acids Res. 1989;17:2503-16.

19. Syrris P, Carter ND, Metcalfe JC, et al. Transforming growth factorbeta1 gene polymorphisms and coronary artery disease. Clin Sci (Lond). 1998;95:659-67.

20. Berndt SI, Huang WY, Chatterjee N, et al. Transforming growth factor beta 1 (TGFB1) gene polymorphisms and risk of advanced colorectal adenoma. Carcinogenesis. 2007;28: 1965-70.

21. August $P$, Suthanthiran M. Transforming growth factor beta signaling, vascular remodeling, and hypertension. N Engl J Med. 2006; 354:2721-3

22. Yamada Y, Miyauchi A, Takagi Y, Tanaka M, Mizuno M, Harada A. Association of the C-509-- $\mathrm{T}$ polymorphism, alone or in combination with the T869-->C polymorphism, of the transforming growth factor-betal gene with bone mineral density and genetic susceptibility to osteoporosis in Japanese women. J Mol Med (Berl). 2001;79:149-56. 